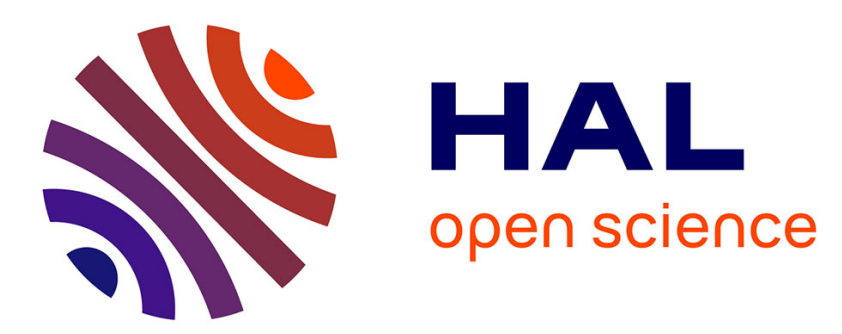

\title{
Living in Singapore: Housing Policies between Nation Building Processes, Social Control and the Market
}

\author{
Denis Bocquet
}

\section{To cite this version:}

Denis Bocquet. Living in Singapore: Housing Policies between Nation Building Processes, Social Control and the Market. Territorio, 2015, Domesticating East Asian Cities (guest edited by Filippo De Pieri and Michele Bonino), 74, pp.35-43. 10.3280/TR2015-074006 . hal-01224147

\section{HAL Id: hal-01224147 \\ https://hal.science/hal-01224147}

Submitted on 5 Nov 2015

HAL is a multi-disciplinary open access archive for the deposit and dissemination of scientific research documents, whether they are published or not. The documents may come from teaching and research institutions in France or abroad, or from public or private research centers.
L'archive ouverte pluridisciplinaire HAL, est destinée au dépôt et à la diffusion de documents scientifiques de niveau recherche, publiés ou non, émanant des établissements d'enseignement et de recherche français ou étrangers, des laboratoires publics ou privés. 


\section{Living in Singapore: housing policies between nation-building processes, social control and the market}

Denis Bocquet (Ecole nationale supérieure d'architecture de Strasbourg / AMUP research unit)

DOI:10.3280/TR2015-074006

Published in: Territorio, 74, 2015, p.35-43 (part of a special issue guest-edited by Filippo De Pieri and Michele Bonino: Domesticating East Asian Cities).

Please quote as such.

The published version also contains various illustrations from the National Archives of Singapore. It is available for download on the online platform of the publisher:

\section{http://www.francoangeli.it/}

Housing policies have been at the very core of the national ideology of Singapore since the time of independence in 1965. The task of providing a flat to citizens and permanent residents thanks to the efforts of a public institution has not only been one of pragmatic realism, or an aspect of the application of economic theories pertaining to the sphere of developmentalism, it also constituted a central feature in the collective project of a CityState in which social engineering was conceived as a global duty of the ruling party and comprised various aspects of the organization of everyday life, from urban planning to housing or from education to leisure and civic engagement (Balasingamchow-Ravinder Frost, 2009). With about $80 \%$ of the population (5.5 million inhabitants in 2015) housed in flats built by the Housing and Development Board (HDB), an institution part of the Ministry of National Development, Singapore remains in 2015, in spite of the recent diversification of the housing market, one of the cities in the world in which the share of population housed in publicly built estates is the highest. 95\% of the inhabitants of Singapore that are housed in such HDB flats, though, own them on a 99-year lease agreement. In the stronghold of capitalism in South-East Asia, social housing was conceived, since the time of independence, as a way to reinforce private property and the familial values that are attached to it (Tremevan, 1994). The object of the present paper is to analyse the evolution of this ideology of social housing in Singapore from the moment of the invention of the HDB as an instrument of national development and social balance to the period of the necessary adaptation of this heritage to the new needs that emerged twenty years after independence and up to more recent challenges posed by the concurrence of alternative models and social imaginaries of housing, such as those embodied by condominiums.

\section{Housing policies as a pillar of nation-building processes}

During the colonial era, planning in Singapore mostly consisted in the more or less efficient control of private development (Eng-Savage, 2006). The colonial administration refrained from enacting an active process of town planning1. Its action was more one of

\footnotetext{
${ }^{1}$ National Archives of Singapore (NAS): National Archives of India Series, Correspondence of G.B. Coleman,
} 
distant supervision. One principle however was clearly planned by colonial authorities: that of the development of ethnic based districtsalong the Singapore River. Inside each district, the urban organization was left to the private market, outside a few public competences like roads, technical networks and fire prevention. In central Singapore, the most common architectural form of housing was the shophouse. Most of them were over-crowed: multiple familiesended up living in very limited spaces and in highly fragile conditions of hygiene. On the rest of the island, a few Malay villages, the Kampongs, formed the armature of urban growth in colonial times. But with the intensification of immigration to colonial Singapore, from China, India and from the rest of the Malaysian peninsula, housing conditions considerably worsened.Following the results of a 1918 commission of enquiry about housing conditions, the Singapore Improvement Trust (SIT) was created in 1927. It built about 20.000 housing units between this date and 1959, when Singapore was granted self-government. Most flats were proposed under the form of rentals and most SIT estates were situated not far away from the existing city-centre of the time ${ }^{2}$.But the growth of shantytowns was much faster than the deliveries of public flats or than the capacities of the private market to propose affordable housing solutions ${ }^{3}$. Between the consequences of the considerable influx of new populations since the 1930s, damage from World War II resulting from the siege and then occupation of the British colonial city by Japanese troops and the consequences of the uncontrolled growth of shantytowns, the situation, which was already critical before World War II, had turned catastrophic. A 1947 report by the Singapore Housing Committee denounced suchdisastrous housing conditions, obliging colonial authorities to implement more ambitious housing policies ${ }^{4}$. The decision by the SIT, in the early 1950s, in the context of the influence of the British New Towns Act of 1946, to adopt (and accommodate to the specific local conditions) the model of the British New Towns is to be interpreted as a response to this urgent need.The first example of new town was that of Queenstown in 1952. But during the 1950s the situation of housing in Singapore did not really change, urban growth largely compensating the construction of the first estates in the new towns. This is why the improvement of housing conditions became one of the key issues in the 1959 electoral campaign that marked the passage to self-government. The PAP (People's Action Party) managed to convince voters about its capacity to tackle the problem better than the widely criticized colonial SIT. In 1960, the SIT was replaced by the Housing and Development Board (HDB) ${ }^{5}$, an institution that was to become almost immediately one of the key actors of social policies in the city (Fernandez, 2011).One of the most important decisions of the HDB in its early years was to retain the model of the new town inherited from colonial times (Eng, 1992).Toa Payoh is one of the first examples of this line of decisions, followed byJurong East, Tampines, Clementi and Woodlands. Directed by Lim Kim San (1916-2006), the HDB managed quite quickly to act more

\footnotetext{
Superintendent of Public Works (1838), NAB 1670.

2 NAS: SIT 744/50. History and Development of TiongBahru Estate (1950-1953). SIT 854/52: 5 years programme of redevelopment. HB 48/58: Report on Housing for 1949-1952.

${ }^{3}$ For an example of such solutions: NAS: SIT 808/5/50. Squatter's resettlement areas. Erection of prototype low cost housing unit (1953).

${ }^{4}$ NAS: SIT $475 / 47$.

${ }^{5}$ NAS: 114/60. HDB annual report for 1960.
} 
energetically than the old SIT (Iqbal Latif, 2009). But in the first couple of years it was not more popular than its predecessor, due to an approach towards the inhabitants of the squatter's settlements that was perceived as aggressive. For many, the HDB was an instrument of displacement of the poor. It is only after the 1961 fire of the Bukit HoSwee precarious neighbourhood, in which more than 2000 houses were destroyed and more than 16000 people lost their home that the legitimacy of the HDB became almost unanimously accepted (LohKah Seng, 2013). Theepisode (and the way the ruling party used it in its propaganda) convinced reluctant inhabitants to leave their barracks and accept the proposed new flats ${ }^{6}$. The resorption of the problem took time however, and in 1966, an estimated 300.000 inhabitants still lived in shantytowns, and an estimated another 250.000 in over-crowded and degraded shophouses.But the heritage of shantytowns left by the British colonial period was erased in about a decade, with the construction of tens of thousands of flats in dozens of housing estates at the cost of a huge investment of public money into the social housing sector (Yuen, 2007). The proportion of Singaporeans housed in the public sector grew rapidly, from 9\% in 1960 to about $80 \%$ a couple of decades later. The creation of the HDB was instrumental in the radical change the built volume of housing units experienced during the first years of self-rule and then independence(Wong, Yeh, 1985; Chua, 1997 ; Castells et al., 1990 ;Tan, Sock-Yong, 1991).Between 1960 and 1965 only, more than 50.000 flats were built. The rhythm even accelerated after independence. The Land Acquisition Act of 1966 represented an important step in the constitution of vast land reserves: the Ministry of National development pre-empted large portions of the territory of the city. Capitalism and private property were submitted, in the framework of a quite authoritarian regime at the time (Mauzy and Milne, 2002), to a specific interpretation that allowed public authorities to emancipate largely from the functioning of the private market for the next few decades. Prime Minister Lee Kuan Yew (1923-2015) had already enounced the basic principles of this move in 1964:

"No private land-owner should benefit from development at public expense and the price paid on acquisition for public purposes should not be higher than what the land would have been worth had the Government not contemplated development generally in the area.I said I would introduce legislation which would help to ensure that increases in land values because of public development should benefit the community and not for the land-owner. Land is becoming a scarce commodity and with the mounting pressure on land at present, we must try to control land values for public purposes"7.

What made the action of the HDB one the main pillars of the new national ideology was also the choice, made as early as in1964, when the Home Ownership Scheme was introduced, to propose most new flats under the form of ownership (Vaso, Lee, 2001 ; Field, 1987). From this moment on, the task of providing a home for all citizens, through the work of the HDB became a clear reflection of the new national ideology (Chua, 1991; Sim, 1993). In 1971, those still living in rented flats were offered the possibility to buy

\footnotetext{
${ }^{6}$ NAS, Oral History Section. Interview with Alan ChoeFook Cheong.

${ }^{7}$ NAS: MC. JN.37/64 (PM). Text of the speech by Prime Minister Mr. Lee Kuan Yew in moving the second reading of the Land Acquisition Bill (June 10,1964). See also: NAS: HB 1045/53/11. Procedure regarding the acquisition of land (1963-1971).
} 
them ${ }^{8}$. It was confirmed however that singles were not allowed to buy (it was only in 1991 that single citizens were allowed to buy, and only on the resale market).

The HDB also represented a crucial instrument in the governance of ethnic diversity in the City-State, in the context of recurrent race riots, among which the1950, 1961, 1964 and 1969 events are only the most spectacular examples (Conceicao, 2014). The Singapore of the first years of self-government and independence was a city in which the situation could degenerate any moment both in echo to the political convulsions of neighbouring Malaysia, in which animosity between the Chinese and the Malays was high, and in reaction to the domination of the Chinese elite over the rest of the population in the city itself. Through a careful (and authoritarian) distribution of populations of different ethnic backgrounds in the HDB estates, Singapore's ruling party aimed at avoiding the constitution of ethnic enclaves, and managed to avoid the worsening of the ethnic tensions (Sim, Yu, Han, 2003). All was made in order to avoid the resurgence of inter-communal riots (MuhKhaidudinAljunied, 2009). From this moment on, fashioning new patterns of ethnic coexistence has been one of the central objectives of the mechanisms of social engineering in Singapore, of which the HDB was one of the expressions of instrumental nature (Hsiao Pi, 1995). In 1980 ethnic quotas were formalized as such.

In order to accelerate the access to private property, in 1968, Singapore citizens were allowed to use their Central Provident Fund savings for the acquisition of a HDB flat (Goldblum, 1986). This contributed in integrating even more public housing as one of the key features of the local Singaporean declension of the ideology of the welfare state.The typical Singaporean pattern of housing is thus conditioned by a series of convergent factors, resulting from both strong ideological choices and a very pragmatic approach to housing. From the very beginning, priority was given to Singapore citizens, even if permanent residents were progressively granted access to the HDB programmes (Sin, 2002).But after a first phase dedicated to intense construction, as soon as in the early 1970s came the first reflections on the quality of the estates that were built during the previous decade, and on quality of life in the city-state in general (It Koon, 1976 ; Ching Ling, Chen, 1977 ; Chong Yah, 1978).

\section{Introducing liveability, upgrading the first generation of HDB estates}

HDB flats and estates began to show signs of degradation very early. The first generation of them had been built according to rudimentary industrial principles, in order to answer social needs and political agendas urgently. Just like in many countries, the public housing estates of that time in Singapore proved fragile in their construction, difficult to maintain and showed planning deficiencies that were not easily corrected. This is why various programmes of upgrading of HDB flats and estates were launched between the end of the 1970s and the 1990s. They all aimed not only at correcting the defects of the first generation, but also at introducing patterns of liveability at the scale of the neighbourhood that proved central in enhancing the values of urbanity of the whole city-state.Liveability in the new towns was indeed an issue. The intent of the upgrading programmes was to reinforce the integration of these new towns, derived

${ }^{8}$ NAS : Government Records, HDB, Administration and Finance Secretariat, File 30/410/040. 
from the post-war British model, into the Singaporean landscape (Eng, 1986 ;Eng, 1996). The HDB wished to correct the tendency of new towns becoming enclaves. A specific effort was made as for the articulation with the network of public transportation. In order to increase liveability, the HDB also decided to implement its planning principles at a smaller scale. In 1978 the institution decided to introduce the concept of precinct. The idea was to facilitate social interaction and to correct the impression given by the first generation of HDB estates in the new towns ${ }^{9}$. Each housing block was from that time on considered as a vertical community. This aspect suggests that liveability was also connected to a new phase in the social engineering methods the HDB was the instrument of which ${ }^{10}$. A new kind of urbanity was promoted, relying on the multiplication of situations of interaction.Open sheltered spaces were multiplied. Commensality was favoured by the generalization of collective food courts in the estates. Urbanity, as a value of social and spatial cohesion, was reinforced by the creation not only of schools, social services or sport and leisure areas in the new towns, but also by the generalization at the scale of each estate of public areas of collective eating. When street kiosks were closed during the 1960s for reasons of public hygiene, it was decided that the tradition of street eating had to be maintained ${ }^{11}$. There are more than 100 such spaces throughout the City-State, with more than 1.500 privately run food stands. There are also hundreds of private replicas of this feature of urbanity in shopping malls and various forms of food courts.

During the 1970s, the Ministry of National Development introduced new instruments aiming at a better governance of public land and a better articulation between the planning of the HDB estates, the private housing market and transportation planning (Tang, 2000). After the design of a new concept plan in 1971, following the results of the cooperation programme with the UN development programme (Eng, 1992), in 1972, private developers were granted the right to operate on the private market on a larger scale.In 1974, the Urban Redevelopment Authority was given the responsibility of land use planning and introduced the concept of Urban Design Development Control ${ }^{12}$.A greater care was also provided to the fashioning of pathways and public spaces inside of the HDB estates and in between them (Yuen, Chor, 1998 ;Tanoboriboon, 1986).But the critics against the first HDB flats were not only provoked by their difficult evolution in time. It was also the evolution of the Singaporean society that fostered it. Candidates for a HDB flat were no longer squatters living in a slum, but rather represented the new local middle-class the formidable economic growth the country experienced gave birth to.In order to adapt to this new social need (and political necessity), as early as in 1974, the HDB began to propose flats for the middle-income category of the population.More categories of flats were also created, in order to answer more adequately to the need for variety the population was expressing (Field, 1987; Goh, 2003). This turn was not just a practical one. It meant that social housing in Singapore was not just for the lower classes, but was part of the life experience of almost all Singaporeans (and permanent

\footnotetext{
${ }^{9}$ NAS : Oral History Centre. 001732. Interview with Thai Ker Liu.

${ }^{10}$ For an illustration of this ideology, see: NAS :csc19830603s. Speech by Mr. Chua Sian Chin, Minister of Home Affairs. 03/06/1982.

${ }^{11}$ NAS : Ministry of Environment, Hawkers Dpt, H032/11 VOL 1 (1968-1977). See also:HUAT, 2001 and on the heritage of the colonial urban culture: SAVAGE, 1992.

${ }^{12 N A S}$ : Oral History Centre. 001951. Interview with Eng Liang Tan.
} 
residents). Public housing was confirmed as a pillar of the national ideology even when the nature of the social needs evolved. The development of the resale market of HDB flats (allowed after a minimum period of occupancy) served as a variable of adjustment (Tu and Wong, 2002).In 1992, the Main Upgrading Programme (MUP) was alsolaunched by the HDB, in order to correct what was increasingly perceived as the embarrassing inertia of the problems of the first generation of HDB estates ${ }^{13}$. Within this programme, more than 130.000 apartments were renovated, in 128 different precincts, thanks to the injection of massive amounts of public money. This represented another important decision in the ideology of public housing: it was confirmed that public money could go not only in the construction of the HDB estates, or in the maintenance of the public areas around them, but also in the renovation of the flats themselves, in spite of the fact that they were private properties. In 2007, the Home Improvement Programme replaced the MUP, introducing a more participatory method of renovation ${ }^{14}$. Inhabitants were given the choice of the works they wanted to be implemented in their flats, in contrast with the first stages of the renovation, during which centralized expertise sometimes clashed with local feelings. The intimacy of housing began to be more respected. All flats built before 1986 and not renovated under the MUP were eligible. In 2015, 100.000 more flats have been included into this scheme.In 2007, Prime Minister Lee Hsien Loong announced the launch of a programme aiming at giving a distinct personality to each estate. Landscape tropicalization, in the framework of the idea of Singapore as a 'city in a garden' is part of this effort ${ }^{15}$.In 2007 too, the Neighbourhood Renewal Programme was launched by the HDB, targeting flats built before 1989 that had not been previously upgraded as part of the MUP. As far as HDB flats and estates are concerned, the priority of the authorities has been throughout the 1990s and 2000s to develop programmes aimed at enhancing the quality of life (Tuan Seik et al., 2000 ;Eng, 1997, Eng and Savage, 2006). In contrast with the initial ideology of the HDB, which was of rather egalitarian nature, with few morphological differences between the housing types for the different categories of the population, patterns of stronger differentiation were introduced (Tuan Seik, 2001; Yuen et al., 2006). The range of proposed housing types has been considerably enlarged. During the 1990s, some of the oldest HDB estates were also destroyed, in the framework of the Selective En Bloc Redevelopment Scheme (SERS). But in order to retain neighbourhood cohesion, residents displaced by the redevelopment programmes were offered a new 99-year lease in new buildings nearby. This policy of care for the sensibility of local communities became even more central in the 2000s and 2010s, as more and more grassroots contestation movements emerged from the civil society. The response of the HDB to such claims is part of the response of the whole state and party apparatus to what could appear as a political challenge ${ }^{16}$. The rhetoric of a more careful consultation process of inhabitants is thus part of all the new programmes, with numerous public forums, as well as with the launch of various sociological and anthropological surveys about the use of HDB flats and neighbourhoods by inhabitants in the changing context of a society that has considerably evolved during the last few decades, with more affluent people, more singles and more elderly people.

\footnotetext{
13NAS: gct19920306. Speech by PM Goh Chok Tong, 06/03/1992.

${ }^{14}$ NAS: 20080725965. Speech by Mah Bow Tan, Minister of National Development, 27/07/2008.

15 On the context : NAS : Oral History Centre. 003879. Interview with NG CheowKheng.

16NAS: 20100312010. HDB. Policy changes to support an inclusive and cohesive home. 05/03/2010.
} 


\section{Present challenges to the national ideology of housing in Singapore}

Public housing in Singapore is today facing a series of challenges that put its very nature into questioning. As more and more Singaporeans wish to live in flats that no longer correspond to the model of the early, and even middle HDB flats, even upgraded (Ong, 2000),public housing is more and more facing the concurrence of the private market. In 2006, the Design, Build and Sale Scheme allowed private developers to market more condominiums, amplifying a trend that had begun about a decade earlier. As a result, during the last decade, the urban landscape of Singapore was significantly transformed by the emergence of new housing forms, under the influence of the private market. Condominiums were built in various part of the city state, and local newspapers began to publish every week new advertising campaigns for the next programme. This had an influence not only on the distribution of housing, but also on the dimension of social representation of what housing is. It introduced new social values and images. The new generation of condos features new urban forms: gated communities, architecture expressing values of social distinction. Signature architecture by architects of international fame became a matter of urban image. Reflections at Keppel Bay, by architect Daniel Libeskind is the most famous illustration of this trend.

But condos are not only a challenge to the value of urbanity as inherited from the very beginning of national history. They also induce the use of more private cars, in contrast to the ideology of egalitarian public transportation that was the pendant of that of public housing. As the URA sold land to private developers taken from public land reserves (Pow, 2009), choices regarding spatial planning almost became a matter of national identity. The fact that international investors increasingly bought apartments in these new Singapore condos is also a challenge to the values of urbanity the city-State is so proud of (Tu et al., 2009). Many Chinese, Malaysian, Indonesian and Indian millionaires bought condos in Singapore as a secure investment. These urban enclaves are not very lively, as owners only come a few times a year.Some private programmes have been bought at more than $60 \%$ by non-residents.These private developments also consume a lot of land in a country that has few. They are depending on the evolution of the global economy and of the buying capacities of foreign clients, the highs and lows of which are followed on a daily basis by local journalists (Teo, 2013).Of course, some condos end up rented to local residents, and of course the recourse to the private market is a way for Singaporeans to make their dreams of luxury living come true. But the fact remains that Singapore has been experiencing such a turn in housing recently that the very identity of the city-state is at stake. Even if public authorities always demanded from private developers a minimal respect of the principle of continuity of public pathways, even in the case of gated communities, condos tend to constitute spatial and social enclaves. Keppel Group, for example, was asked to leave the seafront of its Reflections at Keppel Bay luxury residence under the form of a public promenade along the marina ${ }^{17}$. But the impression of an enclave is part of the marketing strategy of the developer anyway.

\footnotetext{
17Interview with DanielLibeskind, March 2012.
} 
In front of this sociological evolution, the HDB adapted its offer to the horizon of expectation of more affluent inhabitants in search for more upmarket flats. Since the 2000s, middle and upper-middle income families are proposed new typologies of HDB flats, mirroring the esthetical values promoted by the private sector. In front of the growing influence among Singaporeans of the imaginary of condo living, the HDB began in the mid-2000s to market apartments that imitate the visual and social codes of this typology(Wang, 2012). The symbol of this new urban form is the Pinnacle@Duxton, a 50 storey building with hanging gardens. It was inaugurated in 200918. It comprises 1848 flats. In a country where condominiums had mostly been reserved until then for expats and a small minority of local millionaires acting on a niche market, this constructive and social model tended to expand during the last years.In 1995, Prime Minister Goh Chok Tong proposed that the HDB envisage to market high-end executive condominiums, in order to offer a regulated perspective to the category of the population that increasingly refused to live according to the standards inherited from the period of national construction. Tan Guong Ching was instrumental in translating this political agenda into reality ${ }^{19}$. The first realizations were sold in 1999. The development of condominiums was also part of Singapore's quest for the status of world-city (Perry et al., 1997) and of there-engineeringprocess of the city-State (Mahizhnan, Tsa Yuan, 1998). It was a matter of urban image, and even of urban marketing (Giok Ling, Shaw, 2004), and part of the will of the authorities to reinvent the basis of prosperity in a post-industrial age. But it also constituted a challenge to the organization of social life at the scale of the various neighbourhoods. Was spatial and social segregation going to put social cohesion at risk? This evolution of the until-then rather egalitarian ideology of the HDB has indeed prompted strong debates in the country. Some today still protest against the fact that some HDB flats have been sold for more than a million Singapore dollars. In the same time, flats for the lower classes of the population tended to be always smaller. "Is this the Singapore that we want? (....) We want our affordable and used-to-be-bigger HDB flats of yesterday back" (Cheng, 2012). Many in Singapore now express a form of nostalgia for the golden age of HDB flats. Forgetting the imperfections of the early constructive models, they focus on the remembrance of communities in which ties were strong between neighbours and in which housing was part of the invention of a new country. Even if between authoritarianism and mediation the People's Action Party managed to pragmatically readjust the paradigm of public housing in the city, major questions are still to be addressed (Austin, 2000 ; Quah, 2010).

\section{Conclusion}

In a time of profound challenge, the future of public housing in Singapore is surely going to be the result of the capacity, or not, of local society to retain the values of urbanity that made the success of the work of the HDB, in spite of the often highly directive method it applied. In the framework of the reflections on how to make Singapore more inclusive (Hock K-S Chan Hoon L, 2013), public housing is identified again by all as a key issue. There is not only the question of the growing spatial and social segregation induced by the diffusion of new habitat models. The reflection on ethnic coexistence is

\footnotetext{
18NAS : document 20091221001.

19 NAS: Oral History Centre. 003133/4.
} 
again on the agenda. In 2010, the HDB decided to officially oppose the constitution of de facto enclaves dedicated to permanent residents in its estates with the introduction of a Singapore Permanent Resident Quota of 5\% per block (the figure does not comprise citizens of Malaysia, as for their "close cultural and historical similarities with Singaporeans") (Wong 2013). But this move does not solve the question of the unequal treatment of inhabitants according to their nationality. Non-Permanent residents are particularly fragile. Workers commuting from Johor Bahru in Malaysia on a daily basis are even more so. No reflection is currently being developed at the scale of the metropolitan area, that is much bigger than just Singapore as a city-State. The actual city, indeed, is bigger than the country, and the question of housing, just like that of transportation or of the ecological footprint, needs to be addressed at the right scale, in spite of the administrative boundaries.

Another question is that of the impact of the Singaporean model in Asia. In 2003, the Building and Development branch of the HDB was privatized (HDB Corporation Pte Ltd) and then took the name of Surbana. While continuing to act as a partner of the HDB in Singapore, it also began operating on the private market in Singapore and abroad. Surbana is co-owned by Temasek Holdings and CapitaLand. In 2010, Surbana built for the HDB the first eco-friendly housing project in the City-State: Treelodge@Punggol20. It was awarded the PlatiniumGreenmark by the Building and Construction Authority ${ }^{21}$. But Surbana is also active in 90 cities in 26 different countries.In January 2015, it was appointed (with Jurong International) to build Andhra Pradesh's new capital city in India $^{22}$. In a global age, every evolution of the conception of housing in Singapore is likely to have an impact at a much larger scale.

\section{References}

Austin I-P (2000) Pragmatism and Public Policy in East Asia: Origins, Adaptations and Developments. Fairmont, Singapore.

Balasingamchow Y-M, Ravinder Frost M (2009) Singapore: A Biography. Didier MilletNational Museum of Singapore, Singapore.

Castells M, Goh L, Kwok R-Y-W (1990) TheShek Kip Mei Syndrome. Economic Development and Public Housing in Honk Kong and Singapore. Pion, London.

Cheng K (2012) Editor's note. Singapore Architect272:14.

Ching Ling T, Chen P (1977) Life and Living Environment in Kampongs and HDB Public Housing Estates in Singapore. Nanyang University Press,Singapore.

Chong Yah L (1978) Economic Development and the Quality of Life in Singapore. Institute of Education, Singapore.

Chua BengHuat (1991) Not Depoliticized but Ideologically Successful: The Public Housing Programme in Singapore. International Journal of Urban and Regional Research 15-1 : 24-41.

Chua B-C (1997) Political Legitimacy and Housing. Stakeholding in Singapore. Routledge, London.

Conceivao Joe (2014), Singapore and the many headed monster, Singapore, ebooklt.com,

\footnotetext{
${ }^{20}$ National Archives of Singapore, Press Release, 28/01/2010 n. 20100204009: “HDB to develop Punggol as first Eco-Town for the tropics".

${ }^{21}$ National Archives of Singapore, Press Release, 16/05/2011, n. 20110523004

22 Channel News Asia, 12/01/2015.
} 
124p.

Eng T-S (1986) New Town Planning and Development in Singapore. Third World Planning Review 8-3 : 251-267.

Eng T-S (1992) Planning Principles in Pre- and Post-Independance Singapore. Town Planning Review 63-2: 163-178.

Eng T-S (1996) Character and Identity in Singapore New Towns : Planner and Resident Perspective. Habitat International 20-2 : 279-294.

Eng T-S (1997) Public Housing in Singapore: Interpreting Quality in the 1990s. Urban Studies 34-3 : 441-452.

EngTeo Sew and Savage Victor (2006), "Singapore Landscape: a historical overview of housing change", Singapore Journal of Tropical Geography, 6-1, p.48-63.

Fernandez W, (2011) Our Homes. 50 Years of Housing a Nation. Straits Times Press, Singapore.

Field B (1987) Public Housing in Singapore. Land Use Policy 4-2 : 147-156.

Giok Ling 0 (2005) Sustainability and Cities: Concept and Assessment. World Scientific, Singapore.

Giok Ling 0, Shaw B (2004) Beyond the Port City. Development and Identity in 21 th Century Singapore. Prentice Hall Pearson, Singapore.

Goh R (2003) Things to a Void: Utopian Discourse, Communality and Constructed Interstices in Singapore. In: Goh R, Yeoh B Theorizing the Southeast Asian City as Text.World Scientific, Singapore.

GoldblumCh (1986) Singapour : une cité-état moderne à l'épreuve de la fondation urbaine, Thèse de l'Université Paris 8.

Hock K-S Chan Hoon L (2013) Singapore Perspective 2012. Singapore Inclusive : Bridging Divides. Institute of Policy Studies, Singapore.

Hsiao Pi M-K (1995) Social Aspects of Public Housing in Singapore : Kinship Ties and Neighbourly Relations. HDB, Singapore.

Huat C-B (2003) Life is not complete without shopping. Consumption culture in Singapore. SUP, Singapore.

Huat C-B Rajah A (2001) Hybridity, Ethnicity and Food in Singapore. In : Wu D, Chee Beng T, Changing Chinese Foodways in Asia.The Chinese University Press, Hong-Kong. Iqbal Latif A-U (2009) Lim Kim San. A Builder of Singapore. Institute of Southeast Asian Studies, Singapore.

It Koon T (1976), Towards a Better Singapore. Singapore Professional Centre, Singapour. Koon Hean C-C (2012) Singapore : Housing a Nation. Urban Solutions 1 : 38-43.

Lee S-M (1986) Dimensions of Aging in Singapore. Journal of Cross-Cultural Gerontology, 1-3 : 239-254.

LohKah Seng (2013), Squatters into Citizens: The 1961 Bukit HoSwee Fire and the Making of Modern Singapore, Singapore, NUS Press.

MahizhnanArun and Lee Tsao Yuan (eds.) (1998), Singapore: Re-Engineering Success, Singapore, Oxford UP.

Mauzy D. and Milne R.S. (2002), Singapore Under the People's Action Party, London Routledge.

MuhKhaidudinAljunied S (2009) Beyond the Rhetoric of Communalism : Violence and the Process of Reconciliation in 1950s Singapore. In :Heng D, MuhKhaidudinAljunied S Reframing Singapore. AUP,Amsterdam.

National Population and Talent Division (2013) A Sustainable Population for a Dynamic Singapore : Population White Paper.

Ong S-E (2000) Housing Affordability and Upward Mobility from Public to Private in 
Singapore. International Real Estate Review 3-1:49-64.

Perry M Kong L, Yeoh B (1997) Singapore: A Developmental City State. Wiley, Chichester. Pow C-P (2009) Public Intervention, Private Aspiration: Gated Communities and the Condominisation of the Housing Landscape in Singapore. Asia-Pacific Viewpoint 50-2 : 215-227.

Quah J-S-T (2010) Public Administration Singapore Style. Talisman, Singapore.

savage V (1992), Street Culture in Colonial Singapore. In :Huat C-B, Edwards N Public Space.SUP, Singapore.

Sim Loo Lee (1993), "Shelter for all: Singapore's strategy for full home ownership by the year 2000", Habitat International, 17-1, p.85-102.

Sim Loo Lee, Yu S-M, Han S-S (2003) Public Housing and Ethnic Integration in Singapore. Habitat International 27-2 : 293-307.

Sin C-H (2002), Segregation and Marginalization within Public Housing: The Disavantaged in Bedok New Town, Singapore. Housing Studies 17-2 : 167-288.

Singh B (2012) Politics and Governance in Singapore. Mc Graw Hill, Singapore.

Suk-Wai C (2013), Keep kampung spirit, even in a big city. The Straits Times February 23.

Tan A, Sock-Yong P (1991) The Singapore Experience in Public Housing. Times Academic Press, Singapore.

Tan N-T (2002) Community Mediation in Singapore : Principles for Community Conflict Resolution. Conflict Resolution Quaterly 19-3 : 289-301.

Tang K-L (2000) Social Welfare Development in East Asia. Palgrave, Houndmills.

Tanoboriboon Y et al. (1986) Pedestrian Characteristics Study in Singapore. Journal of Transportation Engineering 112-3 : 229-235.

Teng L-L-W (2010) Sexual Governance and the Politics of Sex in Singapore. In : Chong T Management of Success: Singapore Revisited. Institute of Southeast Asian Studies, Singapour.

Teo E (2013) Completed and Unsold : No takers for many high-end condos but supply not slowing any time soon. The Straits TimesFebruary 23.

Teo E (2013) Most new-home buyers have HDB addresses. The Straits Times February 28.

Teo P (2004) Changing Landscapes of Singapore. McGraw Hill, Singapore.

Toh F (2012), Rethinking the Suburban Mall. Singapore Architect 272 : 146-151.

Tremevan (1994), The Political Economy of Social Control in Singapore, London, Macmillan, 187p.

Tu y et al. (2009) Turnovers and Housing Price Dynamics : Evidence from Singapore Condominium Market. The Journal of the Real Estate Finance and Economics 38-3 : 254274.

Tuan seik F (2001) Planning and Design of Tampines, an award-winninghigh-rise high density township in Singapore. Cities 18-1 : 33-42

$\mathrm{Tu}$ Yong and Wong Grace (2002), "Public Policies and Public Resale Housing Prices in Singapore", International Real Estate Review, 5-1, p.115-132.

Tuan Seik F, Lan Yuan LWong Khei Mie G (2000) Planning for a Better Quality of Life in Cities. National University of Singapore (School of Building and Real Estate), Singapore.

Vaso s Lee J (2001) Singapore : Social Development, Housing and the Central Provident Fund. International Journal of Social Welfare 10-4 : 276-283.

Wang J (2012), The Developmental State in the Global Hegemony of Neoliberalism : A New Strategy for Public Housing in Singapore. Cities 29-6 : 369-378.

Wong A, Yeh S (1985) Housing a Nation: 25 years of Public Housing in Singapore. Maruzen-HDB, Singapore. 
Wong Daisy (2013), "Estimating Ethnic Preference using ethnic housing quotas in Singapore", Review of Economic Studies, 80-3, 1178-1214.

Yuen Belinda (2005) Searching for Place Identity in Singapore. Habitat International 29$2: 197-214$.

Yuen Belinda (2007) Squatters no more: Singapore Social Housing. Global Urban Development, 3-1 : 1-22

Yuen B, Chor C-H (1998) Pedestrian Streets in Singapore. Transportation 25-3 : 225-242. Yuen B (et al.) (2006) High-Rise Living in Singapore Public Housing. Urban Studies 43-3 : 583-600. 